\title{
REGIONAL FOOD PREFERENCE AND AWARENESS OF REGIONAL LABELS IN VYSOČINA REGION (CZECH REPUBLIC)
}

\author{
Martina Chalupová ${ }^{1}$, Martin Prokop², Stanislav Rojík ${ }^{3}$
}

Received 18 February 2016; Accepted 30 June 2016

\begin{abstract}
The article presents results of research on preference of the regional food in Vysočina Region in the Czech Republic, with main focus on awareness analysis of Vysočina regional labels. Presented findings are a part of longitudinal research that aims to analyse the evolution of Czech regional labels and their impact on regional development. The questionnaire survey was conducted between January and March 2015 on the sample of 819 respondents from the Vysočina Region. The data have been processed with correspondence analysis and showed that half of respondents prefer regional food, but the results differ in each district, the highest preferences were reported in Jihlava and Třebíc districts. Awareness of the regional labels is rising in comparison with results of the research in 2012. To test respondents' knowledge they were asked to identify regional labels: two existing - VYSOČINA Regional Product $₫$, Regional Food Vysočina Region and also nonexistent label From Our Region Vysočina. The awareness of regional labels was tested according to chosen sociodemographic factors: gender, age, residence in each district of the region and residence in town or village.
\end{abstract}

Key words: Vysočina Region, regional food, regional labels, customer research, correspondence analysis

Souhrn: Článek přináší výsledky výzkumu preference regionálních potravin v Kraji Vysočina $\checkmark$ České republice, se zaměřením na analýzu znalosti regionálních systémů značení v Kraji Vysočina. Publikované výsledky jsou částí longitudálního výzkumu, jehož cílem bylo analyzovat vývoj českých regionálních systémů značení a jejich význam pro regionální rozvoj. Dotazníkové šetření bylo realizováno v období leden až březen 2015 na vzorku 819 respondentů z Kraje Vysočina. Získaná data byla statisticky vyhodnocena pomocí korespondenční analýzy a výsledky ukazují, že polovina oslovených respondentů preferuje regionální potraviny, přičemž výsledky se dle okresů liší. Nejvyšší preference regionálních potravin byla zjištěna $v$ okresech Jihlava a Třebíč. Znalost regionálních značkových systémů pak, ve srovnání s výzkumem

\footnotetext{
1 Ing. Martina Chalupová, College of Polytechnics Jihlava, Department of Economic Studies, Tolstého 16, 58601 Jihlava, Czechia, email: martina.chalupova@vspj.cz

${ }^{2}$ Mgr. Martin Prokop, College of Polytechnics Jihlava Department of Mathematics, Tolstého 16, 58601 Jihlava, Czechia, e-mail: martin.prokop@vspj.cz

3 Ing. Stanislav Rojík, Ph.D., Czech University of Life Sciences Prague, Faculty of Economics and Management, Kamýcká 129, 16521 Prague 6-Suchdol, Czechia; e-mail:rojiks@pef.czu.cz
} 
provedeným v roce 2012, vzrostla. Předmětem výzkumu byly dva existující regionální systémy značení v Kraji Vysočina: VYSOČINA Regionální Produkt@ a Regionální potravina Kraj Vysočina a také jedna neexistující značka $-Z$ našeho regionu Vysočina. Znalosti těchto značení byly testovány $v$ závislosti na vybraných sociodemografických faktorech: pohlaví, věku, bydlišti $v$ jednotlivých okresech a bydlišti ve městě nebo na vesnici.

Klíčová slova: Kraj Vysočina, regionální potravina, regionální značení, výzkum chování spotřebitele, korespondenční analýza

\section{Introduction}

Food quality and its origin are the central issues in the current EU food economics (Grunnert, 2013; Markovina, Stewart-Knox and Rankin et al., 2015), it is possible to talk about the shift of the entire food system from 'food from elsewhere' to 'food from here', defining a food patriotism (Schermer, 2015). Increasing trend among consumers to buy regional food reflects rising supply and promotion of such production, it is also affected by the creation of numerous commercial labels for regionally produced food (McEntee, 2010; Forney, Häberli, 2016).

Van Ittersum et al. (2007) define a regional product as one whose quality and (or) fame can be attributed to its region of origin, important attribute is that the product is marketed using the name of the region of origin. Regional food may also be viewed as a part of regional identity or a manifestation of the cultural and economic heritage (Minta, 2015). To satisfy the needs of consumers, reliable information and strong guarantees of the food origin and quality are necessary. Regional food certification labels may play this role, as they are intended to help improve information flow between producers and consumers about the products' characteristics and enable choices to be better in line with their preference (Vecchio and Annunziata; 2011). Regional labels signal above all authenticity and genuineness, it is a sign that the product is actually produced in the region denoted by the name of the product (Bingen, 2012). By using them, producers are able to use associations consumers connect with a specific region and in that way create for products a unique identity. Fonte (2010) depicts also importance of historical context (tradition) - regional labels should express specificity for the respective region. Basic characteristics of labelled regional products often include their respect for environment, proportion of manual work and use of raw materials specific for the region (llbery, Maye, 2007).

The consumers from the Czech Republic have also gradually become more critical in their food choices in the past years; significantly higher preference of the domestic food production (national, as well as regional and local) may be considered as a lasting trend (Skořepa et al., 2009; Turčínková and Kalábová, 2011; Velčovská, Del Chiapa; 2015). Czech consumers are provided with a substantial amount of different food labels that signal origin and quality. They can be divided into three groups: EU, national and regional level (Chalupová and Prokop, 2015). EU has built three systems for promoting and protecting the names of quality agricultural products and foods: known as PDO (protected designation of origin), PGI (protected geographical indication) and TSG (traditional specialty guaranteed). Successful examples of labelled products are Horice Filled Wafers (PGI), Pohořelice Carp (PDO) and Liptov Salami (TSG - together with the Slovak Republic). EU labels still suffer from the low awareness among the Czech consumers as it was demonstrated by the most recent research by Velčovská and Del Chiapa (2015).

At the national level, label Klasa has a dominant position, as it is recognized by the vast majority of customers in the Czech Republic (Horská et al., 2011). It is viewed as a national quality label even though due to EU regulations it cannot be reserved purely for Czech products. Apart from Klasa, food products may carry origin labels such as Czech Made, Česká kvalita (Czech Quality) and Česká chut'ovka (Czech Delicacy) or Český výrobek - garantováno Potravinářskou komorou ČR (Czech Product - guaranteed by the Federation of the Food and Drink Industries of the Czech Republic) - Kašková, Chromý and Kučera (2016) mention 10 national food quality labels on the Czech market in 2015, all of them using national colours and symbols.

First regional labelling schemes were established in the Czech Republic in 2005, their creators got inspired from projects implemented in Great Britain, Austria, Spain and other European 
countries where similar initiatives already existed and they already could evaluate their experiences (Chalupová and Prokop, 2015). The first labels, which became the basis for the future Association of Regional Brands, originated from the project supported by the European Comission "People for Nature, Nature for People". Recently, ARB associates 26 regions with their regional labels, including Vysocina Region (hwww.regionalni-znacky.cz @2015). ${ }^{4}$ All of them have unified graphic design as well as common granting principles. Kašková et al. (2016) noted that in 2015 there were more than 40 labelling schemes on the regional level in Czechia in total (incl. 26 regional labels associated in ARB). ${ }^{5}$

In 2010, the Ministry of Agriculture of the Czech Republic in cooperation with the Agrarian Chamber and the Federation of the Food and Drink Industries presented the project Regional Food. As an important outcome of this project was also the label "Regional Food" that successful local small and medium producers and agriculturists may place on their products. It has a form of competition; Vysočina Region took part in it since its start. The aim of this project is to improve the consumers' awareness of the regional food, referring to its tradition and quality, communicate the benefits brought by the regional food, strengthen its relations to the given region, and emphasize the advantages of consuming local food in relation to the development of a region and, thus, to the support of employment, tourism, etc. (Czech Ministry of Agriculture, 2015).

It is obvious, that Czech consumers are flooded with labels that aim to symbolize quality and origin of the food, as their number rose dramatically over past ten years. Their ability to recognize and differentiate them may be questioned. The main aim of this paper is to present partial results of the longitudinal research about preference of the regional food in Vysočina Region, with emphasis on Vysočina regional labels awareness, as it was the main focus of the research. The article is structured as follows: first it presents Vysočina Region regional labels. Next, methodology and the research on the preference of regional food and awareness of regional labels in Vysočina Region is presented and discussed. The paper concludes with some practical guidance that could assist policymakers and marketers to build more informed decisions regarding Czech consumers knowledge and concern to regional food and its labels.

\section{Materials and methods}

Vysočina Region is known for its hilly, undulating countryside and rural character, it is situated between the two historical lands of Czech Republic - Bohemia and Moravia. As for administrative breakdown, the Region's territory comprises 5 districts (Jihlava, Havlíčkův Brod, Pelřimov, Třebíč and Žd'ár nad Sázavou) - see Figure 1. Vysočina has a tradition of agricultural production, although the Region's natural conditions are below average, caused by the altitude and slope of the territory. Vysočina Region has optimal conditions for production of potatoes, oil plants, pastoral farming). The rural character of Vysočina can be demonstrated with the fact that the average population per municipality amounts to 730 (the lowest number of all the regions in the Czech Republic). The highest number of municipalities comprises those of population under 500 (Czech Statistical Office, 2016).

The research study aimed to determine the level of awareness of the labels: VYSOČINA Regional Product $®$ and Regional Food Vysočina Region. To investigate the ability of respondents from Vysočina Region to recognise and differentiate the labels, authors created non-existent label From Our Region Vysočina. Word "vysočina" means highlands, therefore non-existent label reflects the motive of the hill and it is in green and blue colours that are traditionally associated with Vysočina. Table 1 presents the basic characteristics of the existing labels.

\footnotetext{
${ }^{4}$ Outside Association of the Regional Brands (ARB) there are also other regional labels, e.g. Regional Product of Czech Paradise, West-Bohemian Local Product, Traditional Product of Slovácko or the trademark Tradition of the White Carpathians ${ }^{\circledR}$ that are considered to be established. These labels are also based on similar criteria as ones associated in ARB, but they do not apply them fully and their co-ordinators are not members of ARB.

5 There are 14 regions in the Czech Republic, Vysočina Region is the only region with 2 regional labels (labelling schemes) active on its territory - the lowest number of all the regions.
} 


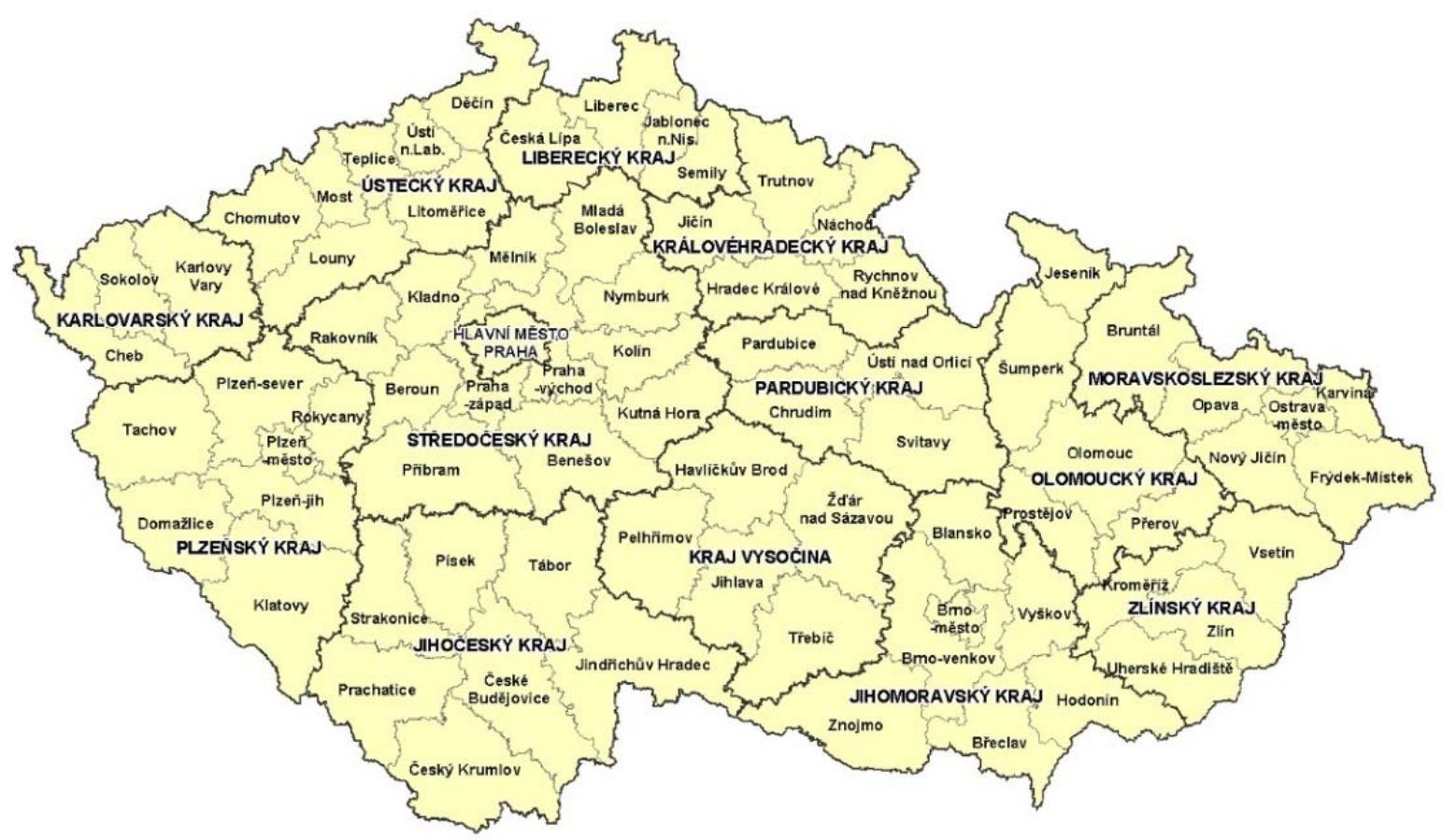

Fig 1. Map of the Czech Republic with location of Vysočina Region and its districts; Source: Český statistický úrad (Czech Statistical Office). Sčitání lidu, domů a bytů - Kraj Vysočina 2011.

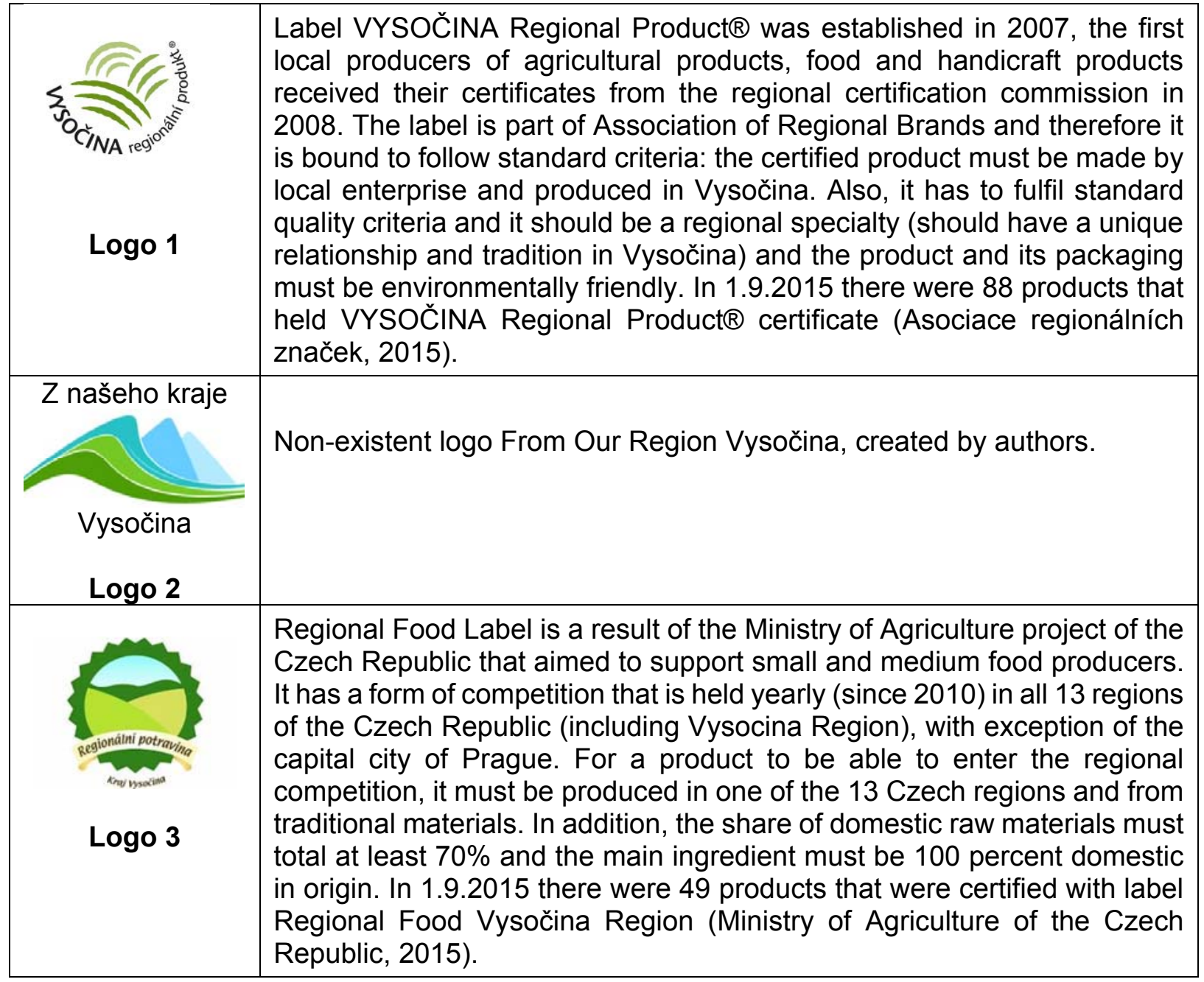

Tab 1. Vysočina Region labels basic characteristics. Source: web presentations of the Vysočina regional labels 
The research was conducted in January - March 2015 in each of the region's district, it had a quantitative design. The structure was determined in accordance with structure of Vysočina Region population as for gender and age groups and districts' residence (see Tab. 2), respondents were also asked to state whether they lived in town or village and also evaluate their household's income (Tab. 3).

Questionnaires were completed with the help of interviewers outside supermarkets and shopping centres, 819 of them were processed. The questionnaire consisted of 25 questions, majority of them (22) were formulated as closed, using numeric (1-7) and Likert Scale to measure respondents' attitudes. Apart from demographic questions and their buying decisions process, respondents were asked to answer the question whether they know any food labels that signal origin or quality (spontaneous awareness) and also whether they recognise presented logos (aided awareness, actual logos of regional labels were presented).

\begin{tabular}{l|l|r|r}
\hline & \multicolumn{3}{|c}{ VYSOČINA REGION } \\
\hline Criterion & Group & Abs. frequency & Rel. frequency \\
\hline \multirow{2}{*}{ Total } & Population aged 15-65 & 344450 & 100.00 \\
\hline \multirow{4}{*}{ Age } & Male & 176875 & $51.3 \%$ \\
\cline { 2 - 4 } & Female & 167575 & $48.7 \%$ \\
\cline { 2 - 4 } & $15-25$ years & 59310 & $17.2 \%$ \\
\cline { 2 - 4 } & $26-35$ years & 69868 & $20.3 \%$ \\
\cline { 2 - 4 } & $36-45$ years & 79507 & $23.1 \%$ \\
\cline { 2 - 4 } & $46-55$ years & 66560 & $19.3 \%$ \\
\cline { 2 - 4 } & $56-65$ years & 69205 & $20.1 \%$ \\
\cline { 2 - 4 } & $65+$ years & 90271 & $17.7 \%$ \\
\hline \multirow{5}{*}{ District } & Jihlava & 112253 & $22 \%$ \\
\cline { 2 - 4 } & Havlíčkův Brod & 94856 & $18.6 \%$ \\
\cline { 2 - 4 } & Pelhřimov & 72323 & $14.2 \%$ \\
\cline { 2 - 4 } & Třebíč & 112464 & $22 \%$ \\
\cline { 2 - 4 } & Žd'ár nad Sázavou & 118626 & $23.2 \%$ \\
\hline
\end{tabular}

Tab 2. Vysočina Region population aged 15-65+ by gender, age groups and districts and respondents group characteristics. Source: Czech statical office, Profile of Vysočina Region 2014

\begin{tabular}{|c|c|c|c|}
\hline & \multicolumn{3}{|c|}{ RESPONDENTS } \\
\hline Criterion & Group & Abs. frequency & Rel. frequency \\
\hline Total & Population aged $15-65$ & 819 & 100.00 \\
\hline \multirow{2}{*}{ Gender } & Male & 418 & $51 \%$ \\
\hline & Female & 401 & $49 \%$ \\
\hline \multirow[t]{6}{*}{ Age } & $15-25$ years & 192 & $23 \%$ \\
\hline & $26-35$ years & 153 & $19 \%$ \\
\hline & $36-45$ years & 171 & $21 \%$ \\
\hline & $46-55$ years & 124 & $15 \%$ \\
\hline & $56-65$ years & 122 & $15 \%$ \\
\hline & $65+$ years & 57 & $7 \%$ \\
\hline \multirow[t]{5}{*}{ District } & Jihlava & 230 & $28 \%$ \\
\hline & Havlíčkův Brod & 93 & $11 \%$ \\
\hline & Pelhřimov & 124 & $15 \%$ \\
\hline & Třebíč & 184 & $23 \%$ \\
\hline & Žd'ár nad Sázavou & 188 & $23 \%$ \\
\hline \multirow[t]{2}{*}{ Residence } & Town & 475 & $58 \%$ \\
\hline & Village & 344 & $42 \%$ \\
\hline \multirow{4}{*}{$\begin{array}{l}\text { Household } \\
\text { income }\end{array}$} & Insufficient & 67 & $8 \%$ \\
\hline & Satisfactory & 342 & $42 \%$ \\
\hline & Substandard & 374 & $46 \%$ \\
\hline & High & 36 & $4 \%$ \\
\hline
\end{tabular}

Tab 3. Respondents' socio-demographic characteristics. Source: own research 
The data have been processed with correspondence analysis (CA), a multivariate statistical technique. The method provides a means of displaying or summarising a set of data in twodimensional graphical form (Nenadić, Greenacre; 2007). Contingency tables are an easy way of displaying relations among categorical data. Depending on the character of the data we then use suitable tests of independence. According to Reezanková (1997), for the case of a contingency table of the $r \times c$ type ( $r$ is the number of rows, $c$ is the number of columns) we most often use the test statistic:

$$
\chi^{2}=\sum_{i} \sum_{j} \frac{\left(n_{i j}-e_{i j}\right)^{2}}{e_{i j}},
$$

$e_{i j}$ is an expected and $n_{i j}$ observed frequency. We use the statistic $X^{2}$ in Pearson's chi-square test with asymptotically $\chi^{2}(r-1)(c-1)$ distribution. The null hypothesis of the test assumes independence. For further details see Hindls (2003). To use the Pearson's chi-square test the condition that maximum $20 \%$ of the expected frequencies are less than five must be met, see Hendl et al. (2007) and Agresti (1990). In other case, see Anděl (2005), we use Fisher's exact test or we calculate simulated $p$-value of $X^{2}$ statistic.

Correspondence analysis (CA) is a multivariate statistical technique. In a similar manner to principal component analysis, it provides a means of displaying or summarising a set of data in two-dimensional graphical form. It is traditionally applied to contingency tables - CA decomposes the chi-squared statistic associated with this table into orthogonal factors. The distance among single points is defined as a chi-squared distance. The distance between $i$-th and $i$ 'th row is given by the formula:

$$
D\left(i, i^{\prime}\right)=\sqrt{\sum_{j=1}^{c} \frac{\left(r_{i j}-r_{i^{\prime} j}\right)^{2}}{c_{j}}},
$$

where $r_{i j}$ are the elements of row profiles matrix $R$ and weights $c j$ are corresponding to the elements of column loadings vector cT, which is equal to mean column profile (centroid) of column profiles in multidimensional space. The distance between columns $j$ and $j^{\prime}$ is defined similarly. The aim of this analysis is to reduce the multidimensional space of row and column profiles and to save maximally original data information (Hebák et al., 2007). The total variance of the data matrix is measured by the inertia, see, e.g., (Greenacre, 1984), which resembles a chisquare statistic but is calculated on relative observed and expected frequencies. Software STATISTICA was used for processing primary data.

\section{Research Results}

The results of the research showed that the majority of respondents, e.g. $52 \%$ (428) take into consideration food origin in Vysočina when shopping, but only seldom. Some $26 \%$ (215) of respondents prefer food from Vysočina, only 6\% (53) strongly prefer food from the region. The minority of respondents $(15 \% ; 123)$ consider the origin of food irrelevant factor for their buying choices. Authors tried to find out if there are differences among inhabitants in Vysočina Region districts. Pearson's chi-square test of independence with the level of $X^{2}=31.78$; sig. $p=0.0015$ $(p<0.05)$ has confirmed that the preference of regional food is strongly dependent on the residence in Vysočina Region districts.

As it is apparent from the Table 4, the lowest preference of the Vysočina regional food is in Žd'ár nad Sázavou district, where almost one fifth of the respondents view origin of the food as irrelevant. On the other hand, respondents from this district also strongly prefer Vysočina food relatively the most $(10 \%$, i.e. the highest preference from all districts). Žd'ár nad Sázavou inhabitants differ from the others - it can be explained by the fact, that inhabitants of this part of Vysočina feel historical closeness to Southern Moravia rather than Vysočina Region (Burda, 2003; Majerová et al., 2011). 
Residence in the Vysočina Region districts

\begin{tabular}{l|r|r|r|r|r}
\hline $\begin{array}{l}\text { When buying food do } \\
\text { you prefer regional } \\
\text { products from } \\
\text { Vysočina? } \\
\text { (Column rel. } \\
\text { frequencies) }\end{array}$ & $\begin{array}{c}\text { Jihlava } \\
\text { JI }\end{array}$ & $\begin{array}{c}\text { Havlíčkův } \\
\text { Brod } \\
\text { HB }\end{array}$ & $\begin{array}{c}\text { Pelhřimov } \\
\text { PE }\end{array}$ & $\begin{array}{c}\text { Třebíč } \\
\text { TRE }\end{array}$ & $\begin{array}{c}\text { Žd'ár nad } \\
\text { Sázavou } \\
\text { ZNS }\end{array}$ \\
\hline A $\begin{array}{l}\text { Origin of the food is } \\
\text { not important for } \\
\text { my choices. }\end{array}$ & $14.78 \%$ & $9.68 \%$ & $8.87 \%$ & $14.13 \%$ & $22.87 \%$ \\
\hline B $\quad \begin{array}{l}\text { I sometimes buy } \\
\text { regional food from } \\
\text { Vysočina. }\end{array}$ & $49.13 \%$ & $60.22 \%$ & $58.87 \%$ & $53.26 \%$ & $46.81 \%$ \\
\hline $\mathbf{C} \quad \begin{array}{l}\text { I try to buy food } \\
\text { from Vysočina } \\
\text { preferentially. }\end{array}$ & $29.57 \%$ & $26.88 \%$ & $23.39 \%$ & $29.89 \%$ & $20.21 \%$ \\
\hline D $\quad \begin{array}{l}\text { I strongly prefer } \\
\text { food from Vysočina }\end{array}$ & $6.52 \%$ & $3.23 \%$ & $8.87 \%$ & $2.72 \%$ & $10.11 \%$ \\
\hline Total column rel. fr. & $100 \%$ & $100 \%$ & $100 \%$ & $100 \%$ & $100 \%$ \\
\hline Pearson chí-sq. test \\
\hline Pearson chí-sq.
\end{tabular}

Tab 4. Preference of the regional food dependant on the place of residence in the Vysočina Region districts. Source: own calculation

Strong preference of the Vysočina origin food (Category D) represents a distant point in the Figure 2, illustrating the fact that in each district it was the least mentioned answer. This information has been also demonstrated in the contingency table (Table 4).

Ability to recognise the food labels was first tested with an open question, which aimed to measure respondents' spontaneous awareness. Almost 53\% (432) of them were not able to name any label; $38 \%$ of all respondents (314), knew national food quality label KLASA, BIO label was named by 23\% (191) of respondents, almost $8 \%$ (62) inhabitants of Vysočina noticed Regional Food label, none named the label VYSOČINA Regional Product. The findings were not surprising, dominant position of KLASA label on the Czech food market has been observed in many researches (e.g. Hes et al., 2008; Skořepa et al., 2009; Horská, Ürgeová, Prokeinová, 2011; Velčovská, Del Chiapa, 2015). The limited capability of respondents to recall food labels spontaneously was observed also on other markets, e.g. Szakály et al. (2015) within a survey made in Hungary about awareness of, attitudes towards, and preferences for food labels (study focused on consumers' reactions to quality and country of origin labels) found out, that $35.5 \%$ of all respondents could not name any such labels.

To test aided awareness of the regional labels, actual logos were presented. Respondents were asked to mark, which of the 3 logos of regional labels (presented in Tab. 1): Vysočina Region Regional Food (Logo 1), non-existent label created by authors From Our Region Vysočina (Logo 2) and VYSOČINA Regional Product (Logo 3) - they noticed when shopping. The question was formulated as follows: ,Please indicate the logo you have noticed when shopping for food'. More than half of respondents (53.8\%, abs. 441) have marked label Regional Food Vysočina Region, one third of them $(31.4 \%$, abs. 257$)$ have indicated label VYSOČINA Regional Product, nonexistent logo was recognised by almost quarter of all respondents $(23.4 \%$, abs. 192). This result indicates that people do not pay enough attention to the labels and consumers find them easily interchangeable, it may also be a signal of the weak image of regional labels and their insufficient marketing communication. The positive fact is that the knowledge of regional label is rising. The research made by the authors in $2012(n=404)$, showed that $36 \%(145)$ respondents have 
recognised label Regional Food Vysočina Region and only 19\% (76) of them identified VYSOČINA Regional Product (Chalupová, Prokop, Rojík, 2012).

Figure 2 presents graphical output of the correspondence analysis, it displays how inhabitants of the Vysočina districts prefer regional food. Nearby points in the graph mean that residents of Jihlava and Třebíč districts try to buy food from Vysočina preferentially (Category C).

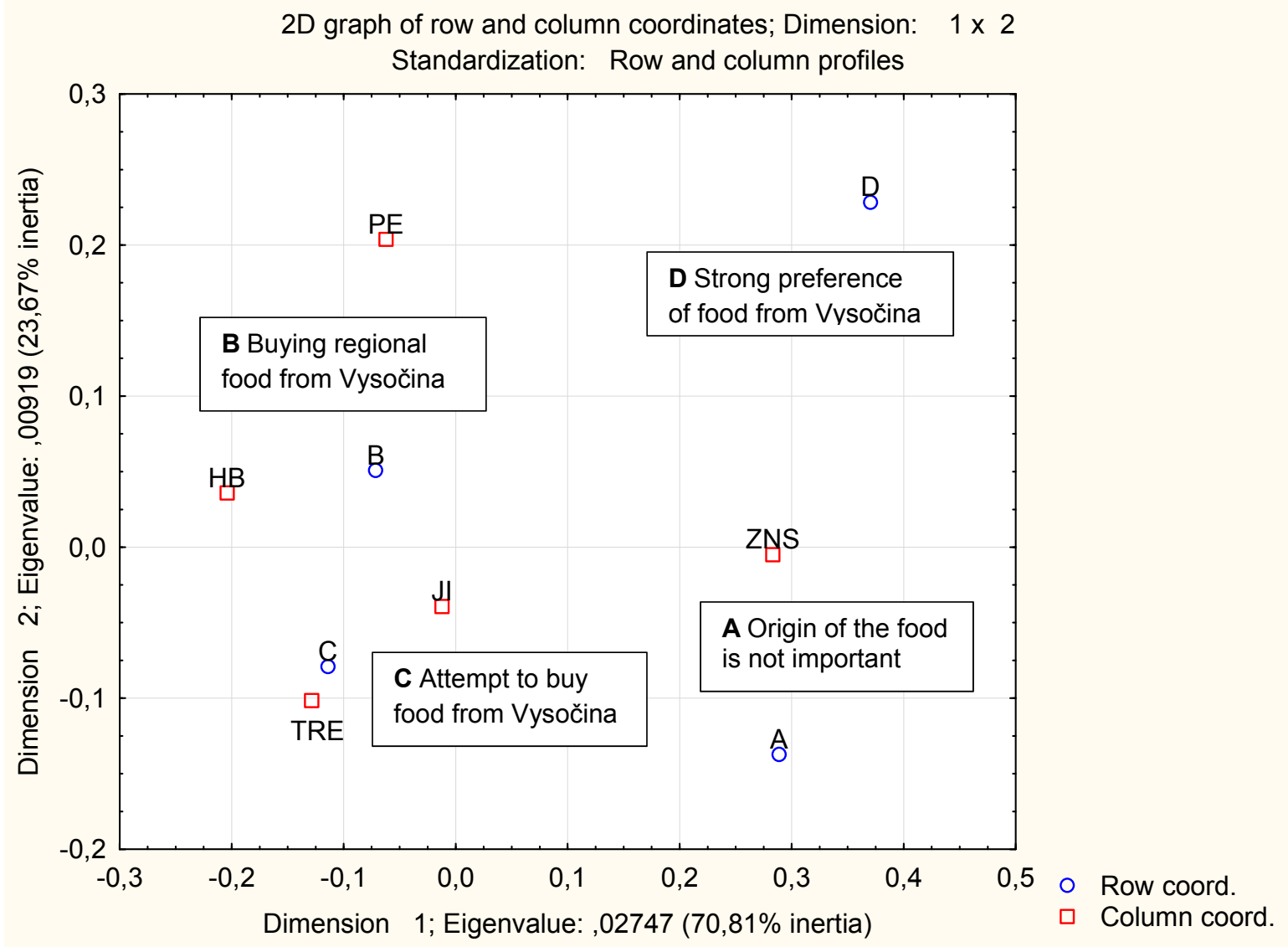

Fig 2. Correspondence analysis - preference of the regional food in the Vysočina Region districts. Source: own calculation

Further results do not include correspondence maps because of two possible facts: proven independence or only two values of one observed variable (should be at least three). When examining results in Table 5, it is clear that the inhabitants of Jihlava, Třebič and Žd'ár nad Sázavou districts state that they are aware of regional labels the most. They recognised label Regional Food Vysočina Region the most (Logo 1), non-existent label From Our Region Vysočina (Logo 2) have been indicated the most frequently in Jihlava district. Pearson's chi-square test of independence with the level of $x^{2}=7.13$; sig. $p=0.523(p>0.05)$ has confirmed that the recognition of tested labels does not depend on place of residence in districts of Vysočina.

When comparing results in Tab. 4 and Tab. 5, a paradox is visible. Ždár nad Sázavou district inhabitants who showed the lowest interest in regional food, are more aware of the regional labels than inhabitants of Pelhřimov and Havlíčkưv Brod districts, who demonstrated subaverage regional food preference. It may be a signal that inhabitants of these districts do not consider the regional labels when shopping for food as the information about its origin and probably rely on their own experience or other sources. 


\begin{tabular}{|c|c|c|c|c|c|c|}
\hline \multicolumn{7}{|c|}{ Residence in the Vysočina Region districts } \\
\hline $\begin{array}{l}\text { Awareness of the } \\
\text { label } \\
\text { (answer YES): } \\
\text { Row rel. frequencies }\end{array}$ & $\begin{array}{c}\text { A } \\
\text { Jihlava }\end{array}$ & $\begin{array}{c}\text { B } \\
\text { Havlíčkův } \\
\text { Brod }\end{array}$ & \begin{tabular}{|c|} 
C \\
Pelhřimov
\end{tabular} & $\begin{array}{c}\text { D } \\
\text { Třebíč }\end{array}$ & \begin{tabular}{c|} 
E \\
Žd'ár nad \\
Sázavou
\end{tabular} & Total \\
\hline Logo 1 & $28.81 \%$ & $11.90 \%$ & $12.38 \%$ & $24.52 \%$ & $22.38 \%$ & $100 \%$ \\
\hline Logo 2 & $31.15 \%$ & $12.57 \%$ & $16.39 \%$ & $21.31 \%$ & $18.58 \%$ & $100 \%$ \\
\hline Logo 3 & $25.90 \%$ & $11.16 \%$ & $11.16 \%$ & $25.90 \%$ & $25.90 \%$ & $100 \%$ \\
\hline Pearson chi-sq. test & \multicolumn{2}{|c|}{$x^{2}$} & & & \multicolumn{2}{|l|}{$\mathbf{P}$} \\
\hline Pearson chi-sq. & \multicolumn{2}{|r|}{7.130239} & \multicolumn{2}{|r|}{$\mathrm{df}=8$} & \multicolumn{2}{|c|}{$\mathrm{p}=0.52265$} \\
\hline
\end{tabular}

Tab 5. Awareness of the regional labels in the districts of Vysočina Region. Source: own calculation

Dependence of the awareness of Vysočina regional labels and respondents' residence in town/village was also tested, results showed strong dependence (Pearson's chi-square test of independence with the level of $X^{2}=7.68$; sig. $\left.p=0.02149, p<0.05\right)$. As it is apparent from Tab. 6 , respondents who claimed that they live in town have recognised label Regional Food Vysočina Region (Logo 1) significantly more - slightly more than $67 \%$, people with residence in a village have recognised this logo less $(32.86 \%)$. The same results showed the analysis of VYSOČINA Regional Product label (Logo 3) awareness (almost $60 \%$ of those who lived in towns have noticed it when shopping for food). Interesting is that respondents from towns recognised the most nonexistent logo (Logo 2) (71.58\%). It can be stated that towns' residents are more aware of the existence of regional labels in general, but do not pay attention to them.

\begin{tabular}{|c|c|c|c|}
\hline \multirow[b]{2}{*}{$\begin{array}{l}\text { Awareness of the } \\
\text { label } \\
\text { (answer YES): } \\
\text { Row rel. frequencies }\end{array}$} & \multicolumn{3}{|c|}{ Residence: Town/Village } \\
\hline & Town & Village & Total \\
\hline Logo 1 & $67.14 \%$ & $32.86 \%$ & $100 \%$ \\
\hline$\sum_{\text {wsotien }}$ & $71.58 \%$ & $28.42 \%$ & $100 \%$ \\
\hline Logo 3 & $59.36 \%$ & $40.64 \%$ & $100 \%$ \\
\hline Pearson chi-sq. test & $x^{2}$ & & $\mathbf{P}$ \\
\hline Pearson chi-sq. & 7.680800 & $d f=2$ & $p=0.02149$ \\
\hline
\end{tabular}

Tab 6. Awareness of the regional labels in Vysočina Region - dependence on the residence in the town or village. Source: own research

Further analysis focused on the differences between male and female respondents' awareness of the Vysočina regional labels. As it is apparent from Table 7, women pay more attention to the labels $(60 \%$ of them stated they noticed each label). Statistical testing confirmed the independence between respondents' gender and their awareness of regional labels in Vysočina: $X^{2}=7.143$; sig. $p=0.931$ ( $p>0.05$ ). Velčovská's (2012) research on food quality labels on the Czech market came up with very similar results. Both researches' results correspond with analysis made by Schupp and Gillespie (2001), as well as Loureiro and Umberger (2005), who tested support for compulsory country-of-origin labelling, that men generally tend to pay less attention to information in connection with the purchase of the food. 


\begin{tabular}{|c|c|c|c|}
\hline \multicolumn{4}{|c|}{ Gender } \\
\hline $\begin{array}{l}\text { Awareness of the label } \\
\text { (answer YES): } \\
\text { Row rel. frequencies } \\
\end{array}$ & Female & Male & Total \\
\hline Logo 1 & $61.19 \%$ & $38.81 \%$ & $100 \%$ \\
\hline 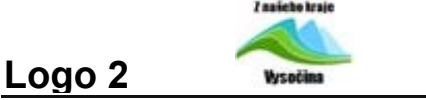 & $59.56 \%$ & $40.44 \%$ & $100 \%$ \\
\hline Logo 3 & $60.56 \%$ & $39.44 \%$ & $100 \%$ \\
\hline Pearson chi-sq. test & $x^{2}$ & & $\mathbf{P}$ \\
\hline Pearson chi-sq. & 7.1429255 & $\mathrm{df}=2$ & $p=0.93103$ \\
\hline
\end{tabular}

Tab 7. Awareness of the Vysočina regional labels according to respondents' gender. Source: own calculation

Analysis of the regional labels' awareness in connection with respondents' age showed no significant dependence: $x^{2}=6.767$; sig. $p=0.747 \quad(p>0.05)$, the chosen age groups have recognised each of the presented logos at the same level (Tab. 8). The highest awareness of the logos was among the youngest respondents (up to 25 years), which is in line with Rojík's (2014) research findings, who tested awareness of the regional labels among consumers in Lower Austria, and lower age categories have recognised the tested regional labels the most, as well. It signals that younger consumers might be considering origin of the food in the region as relatively important factor for their choices and they might find regional labels as a useful lead when shopping for food. Respondents aged over 65 years have been aware of the Vysočina regional labels the least (awareness of each label was around $7 \%$ in comparison with $21 \%$ average result with youngest respondents). It is obvious that when shopping for food these respondents consider more other factors (such as price or health benefits) than its origin in the region (as it was indicated by Loureiro and Umberger, 2005).

\begin{tabular}{|c|c|c|c|c|c|c|c|}
\hline \multicolumn{8}{|c|}{ Respondents' age groups } \\
\hline $\begin{array}{l}\text { Awareness of the } \\
\text { label } \\
\text { (answer YES): } \\
\text { Row rel. frequenc } \\
\end{array}$ & $\begin{array}{l}\text { Up to } 25 \\
\text { years }\end{array}$ & $\begin{array}{l}26-35 \\
\text { years }\end{array}$ & $\begin{array}{l}36-45 \\
\text { years }\end{array}$ & $\begin{array}{l}46-55 \\
\text { years }\end{array}$ & $\begin{array}{l}56-65 \\
\text { years }\end{array}$ & $\begin{array}{c}\text { Over } 65 \\
\text { years }\end{array}$ & Total \\
\hline Logo 1 & $22.38 \%$ & $19.29 \%$ & $22.38 \%$ & $13.33 \%$ & $15.00 \%$ & $7.62 \%$ & $100 \%$ \\
\hline Logo 2 & $20.22 \%$ & $21.31 \%$ & $16.94 \%$ & $16.94 \%$ & $17.49 \%$ & $7.10 \%$ & $100 \%$ \\
\hline Logo 3 & $21.12 \%$ & $18.33 \%$ & $19.52 \%$ & $18.73 \%$ & $15.94 \%$ & $6.37 \%$ & $100 \%$ \\
\hline \multicolumn{2}{|c|}{ Pearson chi-sq. test } & \multicolumn{2}{|c|}{$\frac{1}{x^{2}}$} & & & \multicolumn{2}{|c|}{$\mathbf{p}$} \\
\hline \multicolumn{2}{|c|}{ Pearson chi-sq. } & \multicolumn{2}{|c|}{6.766766} & \multicolumn{2}{|r|}{$d f=10$} & \multicolumn{2}{|c|}{$p=0.74726$} \\
\hline
\end{tabular}

Tab 8. Awareness of the regional labels in Vysočina Region - dependence on the respondents' age. Source: Own calculation

Dependence of the awareness of Vysočina regional labels and respondents' evaluation of their household's income was also tested - results showed independence between the two variables with Pearson's chi-square test of independence level of $X^{2}=6.0035$; sig. $p=0.4228, p>0.05$ ). Results in Table 9 demonstrate that respondents who has indicated their household income as ,substandard', i.e. one when household covers all needs within a reasonable range, and those with household income at satisfactory level (a household can cover all the basic needs, such as 
food, rent, clothing etc.) have been aware of regional labels the most. People with high income have the worst knowledge of regional labels, it may be a signal that when shopping for food these consumers consider other factors to be important than origin in the region, e.g. price may be a strong and satisfactory symbol of the products' quality.

\begin{tabular}{|c|c|c|c|c|c|}
\hline \multicolumn{6}{|c|}{ Household income evaluation } \\
\hline $\begin{array}{l}\text { Awareness of the label } \\
\text { (answer YES): } \\
\text { Row rel. frequencies }\end{array}$ & Insufficient & Satisfactory & $\begin{array}{c}\text { Substandar } \\
\text { d }\end{array}$ & High & Total \\
\hline Logo 1 & $8.10 \%$ & $40.48 \%$ & $46.19 \%$ & $5.24 \%$ & $100 \%$ \\
\hline Logo $2 \overbrace{\text { wsotim }}^{N}$ & $11.48 \%$ & $42.62 \%$ & $42.08 \%$ & $3.83 \%$ & $100 \%$ \\
\hline Logo 3 & $8.76 \%$ & $39.04 \%$ & $44.22 \%$ & $7.97 \%$ & $100 \%$ \\
\hline Pearson chi-sq. test & \multicolumn{2}{|c|}{$x^{2}$} & & \multicolumn{2}{|c|}{$\mathbf{P}$} \\
\hline Pearson chi-sq. & & 6.003471 & $d f=6$ & & $p=0.42280$ \\
\hline
\end{tabular}

Tab 9. Awareness of the regional labels in Vysočina Region - dependence on the respondents' household income evaluation. Source: Own calculation

\section{Conclusion}

The application and market presence of regional food quality and authenticity schemes is quite diverse across Europe. Verbeke (2013) indicated, that EU member states have gone different ways in their food quality and labelling policies, which reflects differences in historical evolution, organisation and development of food industries, as well as different consumer interests, attitudes and behaviour. Presented results of the research could be viewed as a sign of the food labels inflation - with their rising number it is impossible for the consumers to differentiate them or pay attention to them (all that with considering the fact that Vysočina Region has the lowest number of regional labels on its territory among all the Czech regions).

Spontaneous awareness of the quality and origin food labels of the respondents is quite low, as half of them were not able to name any label, the research also proved a dominant position of national food quality label KLASA as $38 \%$ of all respondents have named it. Test of the aided awareness of Vysočina regional labels showed, that respondents know about their existence half of them stated they have already seen Regional Food Vysočina Region logo when shopping and almost third of them recognised label VYSOČINA regional product. Relatively high number of respondents (24\%) claimed they have already seen non-existent label. Awareness of the regional labels was also tested with dependence on chosen sociodemographic characteristics of respondents. Our findings confirmed that significant differences do exist between respondents' residence (town/village) and their awareness of the regional labels; no significant difference was found based on gender, age, and household's income evaluation. However, it can be suggested that stakeholders involved in regional labelling schemes should focus on the lower age categories of consumers, as the findings suggest they might be considering regional labels as the lead when shopping for food. They should provide them with valid information to strengthen their interest in regional food, using well targeted marketing communication. As Verbeke (2013, p. 15) stressed: ,for labels to have value for consumers, they must be communicated, attented to and understood in the first instance' (this condition is often not fulfilled).

The research has revealed that half of respondents from Vysočina take into consideration food origin in the Region when shopping, but only seldom, the quarter of them prefer regional food. It signals that people in Vysočina Region can be viewed as food patriots, which is in line with research of Kalábová and Turčínková (2011). Further analysis confirmed that the preference of regional food is strongly dependent on the residence in Vysočina Region districts. The lowest preference of the Vysočina regional food is in Žd'ár nad Sázavou district, respondents from this 
district differ in their preferences from the others - it can be explained by the fact, that inhabitants of this part of Vysočina feel historical closeness to Southern Moravia (Burda, 2003). These results should be an aim of the further research that would focus on the findings how regional food can become a factor that could play a role in strengthening Vysočina regional identity.

Policy makers have already recognised importance of regional food products as a mean to support identity and economy of the region (Velčovská, Del Chiapa, 2015). With more than one regional label per region it is highly important to build a label strong, distinctive positioning, so that it may also represent a protection of the authentic production. To do so, there is a pressing need to increase consumers' confidence for regional labels through dissemination of reliable information. At the moment any producer who will place on his/her production label that would signal origin in Vysočina may exploit image of existing labels.

Aside from the practical contribution of the study, the authors are aware of some limitations. First, the presented article adopted quite basic statistics (correspondence analysis and chi-square tests). Further research should run a cluster analysis to profile Czech customers with preference of regional food and awareness of regional labels. It should be also tested whether the awareness of the regional labels might be more dependent on the attitudes of the respondents towards their own region, their lifestyle and beliefs.

\section{References}

[1] Agresti, A. (1990). Categorical Data Analysis. New York: John Wiley a Sons.

[2] Anděl, J. (2005). Základy matematické statistiky. Praha: Matfyzpress.

[3] Bingen, J. (2012). Labels of Origin for Food, the New Economy and Opportunities for Rural Development in the US, Agriculture and Human Values, 29(4), 543-552, DOI: $10.1007 / \mathrm{s} 10460-012-9400-z$.

[4] Blasius, J. \& Greenacre, M. J. (1994). Computation of Correspondence Analysis (pp. 53-75). In Greenacre, M. J. \& Blasius, J., eds., Correspondence Analysis in the Social Sciences, London: Academic Press.

[5] Burda, T. (2003). „Nové okresy“ ve světle reformy veřejné správy (pp. 114-123). In Jančák, V., Chromý, P. \& Marada, M., eds., Geografie na cestách poznání. Praha: Univerzita Karlova.

[6] Český statistický úřad (2016). Sčitání lidu, domů a bytů - Kraj Vysočina 2011.

[7] Český statistický úřad (2015): Vysočina Region. Praha, 2015. In: [online]. [cit. 2016-02-03]. Retrieved from: https://www.czso.cz/csu/czso/zakladni-tendence-demografickehosocialniho-a-ekonomickeho-vyvoje-kraje-vysocina-2013-dsdmcqx1nq.

[8] Chalupová, M. \& Prokop, M. (2015). Regional Brands In Vysocina Region - Do Consumers See Differences? (pp. 297-307). In Proceedings ICABR 2014. Brno: Mendel University.

[9] Chalupová, M., Rojík, S. \& Prokop, M. (2012). Znalost regionálních značek potravin v Kraji Vysočina. Trendy v podnikání 2(3), 72-82.

[10] Forney, J. \& Häberli, I. (2016). Introducing 'Seeds of Change' into the Food System? Localisation Strategies in the Swiss Dairy Industry. Sociologia Ruralis 56(2), 135-156. DOI: 10.1111/soru.12072.

[11] Fonte, M. (2010). The construction of origin certification. Knowledge and local food (pp. 149171). In Fonte, M. \& Papadopoulos, A. G., eds., Naming food after places. Food relocalization and knowledge dynamics in rural development. Farnham: Ashgate.

[12] Grunert, K. G. (2013). Trends in food choice and nutrition. In M. Klopčič et al., eds., Consumer attitudes to food quality products; Emphasis on Southern Europe, EAAP publication No. 133, Wagenigen Academic Publishers. DOI 10.3920/978-90-8686-762-2_2.

[13] Hebák, P., Hustopecký, J. \& Malá, I. (2007). Vícerozměrné statistické metody. Praha: Informatorium, spol. s.r.o. 
[14] Hes, A. a kol. (2008). Chování spotřebitele prì nákupu potravin Praha: Alfa.

[15] Hindls, R. (2003). Statistika pro ekonomy. $3^{\text {rd }}$ ed. Praha: Professional Publishing.

[16] Horská, E., Ürgeová, J. \& Prokeinová, R. (2011). Consumers' food choice and quality perception: Comparative analysis of selected Central European countries. Agricultural Economics - Czech, 57(10), 493-499.

[17] Ilbery, B. \& Maye, D. (2007). Marketing sustainable food production in Europe: case study evidence from two Dutch labelling schemes. Tijdschrift voor Economische en Sociale Geografie. 98(4), 507-518. DOI: 10.1111/j.1467-9663.2007.00418.x.

[18] Ittersum van, K., Meulenberg, M.T.G., Trijp, H.C.M. \& Candel, M.J.J.M. (2007). Consumers‘ Appreciation of Regional Certification Labels: A Pan-European Study, Journal of Agricultural Economics, 58(1), 1-23. DOI: 10.1111/j.1477-9552.2007.00080.x.

[19] Kalábová, J. \& Turčínková, J. (2011). Preferences of Consumers When Shopping for Regional Products. Economic Science for Rural Development. 28, 56-60.

[20] Kašková, M. \& Chromý, P. (2014). Regional product labelling as part of the region formation process. The case of Czechia. In AUC Geographica 49(2), 87-98. DOI: http://dx.doi.org/10.14712/23361980.2014.18.

[21] Kašková, M., Chromý, P. \& Kučera, Z. (2016). Regional labelling schemes constituing and reflecting the process of regions and regional identities construction. The case of Czechia. AAG Annual Meeting, San Francisco.

[22] Loureiro, M. L. \& Umberger, W. J. (2005). Assessing Consumer Preferences for Country-ofOrigin Labelling. Journal of Agricultural and Applied Economics, 37(1), 49-63.

[23] Majerová, V., Kostelecký, T., Sýkora, L., Vajdová, Z. \& Matoušek, R. (2011): Sociální kapitál a rozvoj regionu. Příklad Kraje Vysočina. Praha: Grada.

[24] Markovina, J., Stewart-Knox, B. J., Rankin, A., Gibney, M., De Almeida, M. D. V., Fischer, A., Kuznesof, S. A., Poínhos, R., Panzona, L. \& Frewer, L. J. (2015). Food4Me study: Validity and reliability of Food Choice Questionnaire in 9 European countries. Food Quality and Preference 45(10), 26-32. DOI: 10.1016/j.foodqual.2015.05.002.

[25] McEntee, J. (2010). Contemporary and Traditional Localism: Conceptualisation of Rural Local Food. Local Environment: The International Journal of Justice and Sustainability, 15(9), 785-803. DOI: 10.1080/13549839.2010.509390.

[26] Minta, S. (2015). Regional food products: only for tourists or also for residents. Agriculture \& Forestry, 61(1), 51-58. DOI: 10.17707/AgricultForest.61.1.06.

[27] Nenadić, O. \& Greenacre, M. J. (2007). Correspondence Analysis in R, with Two- and Threedimensional Graphics: The ca Package. Journal of Statistical Software. 20(3), 1-13.

[28] Regionální potraviny. Ministry of Agriculture of the Czech Republic [online]. [Accessed 201506-03]. Retrieved from: <http://eagri.cz/public/web/regionalni_potraviny>

[29] Schermer, M. (2015). From „Food from Nowhere“ to „Food from Here“: changing producerconsumer relations in Austria. Agricultural Human Values. 32, 121-132. DOI: 10.1007/s10460-014-9529-z.

[30] Schupp, A. \& Gillespie, J. (2001). Consumer Attitudes toward Potential Country-of-Origin Labeling Fresh or Frozen Beef. Journal of Food Distribution Research, 32(3), 34-44.

[31] Skořepa, L. et al. (2009). Regionální trh potravin. České Budějovice: Jih pro Jednotu.

[32] Spilková, J. \& Fialová, D. (2013). Building fertile links with regional brands: The case of Czech regional products (pp. 215-235). In Figueiredo, E. \& Raschi, A., eds., Fertile Links? Connections between tourism activities, socioeconomic contexts and local development in European rural areas. Firenze University Press. 
[33] Szakály, Z., Soós, M., Szabó, S. \& Szente, V. (2015). Role of labels referring to quality and country of origin in food consumers' decisions. Acta Alimentaria. 44(2). DOI: http://dx.doi.org/10.1556/AAlim.2015.0012.

[34] Turčínková, J. \& Kalábová, J. (2011). Preference regionálních potravinářských produktů v České republice a na Slovensku (pp. 206-209). In Petranová, D. \& Čábyová, L'., eds., Špecifiká regionálneho a neziskového marketingu. Trnava: University of Ss. Cyril and Methodius.

[35] Vecchio, R. \& Annunziata, A. (2011). The role of PDO/PGI labelling in Italian consumers' food choices. Agricultural Economic Review, 12(2), 80-98.

[36] Velčovská, Š. (2012). Food Quality Labels and their Perception by Consumers in the Czech Republic. World Academy of Science, Engineering and Technology, 66, 154-160.

[37] Velčovská, Š. \& Del Chiapa, G. (2015). The Food Quality Labels: Awareness and Willingness to Pay in the Context of the Czech Republic. Acta Univ. Agric. Silvic. Mendelianae Brun. 63(2), 647-658. DOI: 10.11118/actaun201563020647.

[38] Verbeke, W. (2013). Food quality policies and consumer interests in the EU. In Klopčič, M. et al., eds., Consumer attitudes to food quality products; Emphasis on Southern Europe, EAAP publication No. 133, Wagenigen Academic Publishers. DOI 10.3920/978-90-8686762-2 2.

[39] Značení místních výrobků, produktů a služeb. Asociace regionálních značek. [online]. [Accessed 2015-06-03]. Retrieved from: <http://www.arz.cz/o_znaceni.htm> 